\title{
The effect of clenbuterol on basal protein turnover and endogenous nitrogen loss of sheep
}

\author{
BY J. E. INK STER, F. D. DEB. HOVELL*, D. J. KYLE, D. S. BROWN \\ AND G. E. LOBLEY \\ Rowett Research Institute, Bucksburn, Aberdeen AB2 9SB
}

(Received 18 October 1988 - Accepted 22 May 1989)

\begin{abstract}
Seven measurements of the effect of clenbuterol on basal nitrogen excretion $\left(U N_{E}\right)$, and protein turnover were made in six female sheep. The sheep were sustained by the intraruminal infusion of energy as volatile fatty acids to provide maintenance, but given no protein ( $N$-free) for $12 \mathrm{~d}$ (6 d control, $6 \mathrm{~d}$ clenbuterol). Clenbuterol reduced $\mathrm{UN}_{\mathrm{E}}$ by $20 \%$, but only on day 2 of the $6 \mathrm{~d}$ subperiod. Protein flux (equivalent to degradation on $\mathrm{N}$-free nutrition), measured on day 6 by the irreversible loss of leucine was significantly increased $(12 \%)$ by clenbuterol. Amino- $N$ oxidation measured by $N$ excretion was unchanged and, therefore, protein synthesis was also increased. During the $12 \mathrm{~d}$ N-free period, the recovery of urinary total $\mathbf{N}$ (Kjeldahl) as the sum of urea, ammonia, creatinine and purine derivatives, declined from 87.7 to $74.2 \%$. The form of this missing $N$ was not identified. The effect of clenbuterol of increasing both degradation and synthesis is unlike that reported in the literature for animals receiving protein when, in general, synthesis is unchanged and degradation reduced. This could be due to a different effect of clenbuterol in the $\mathrm{N}$-free state, or to unchanged effects on protein pools other than muscle whose relative contribution to protein metabolism is different in the $\mathrm{N}$-free state.
\end{abstract}

Clenbuterol: Protein turnover: Nitrogen loss: Sheep

We have reported (Hovell et al. 1989) that the $\beta_{2}$-adrenergic agonist clenbuterol reduced the endogenous nitrogen loss of sheep. That experiment was based on the hypothesis that the increase in $\mathrm{N}$ retention caused by the $\beta_{2}$-agonists in animals given dietary protein is mediated by a decrease in body protein degradation (Reeds et al. 1986; Buttery \& Dawson, 1987). We had, therefore, reasoned that the $\beta_{2}$-agonists might reduce the endogenous $N$ loss of animals given energy, but no protein, and found that clenbuterol did significantly reduce endogenous $\mathbf{N}$ losses. Clearly, such an effect could be mediated by the drug modifying either protein synthesis, or degradation, or both, with the net effect that a reduced amount of amino acid would be lost to oxidation. The objective of the work to be reported here was to extend our observations on the effect of clenbuterol on basal $\mathrm{N}$ loss to measurements of protein turnover.

\section{MATERIALS AND METHODS \\ Treatments and design}

Seven measurements were made of the daily endogenous $N$ loss $\left(U N_{E}\right)$ during a 12 d period in six sheep (one sheep measured twice) given energy as an infusion of volatile fatty acids (VFA) into the rumen, but no protein ( $\mathrm{N}$-free period). The $12 \mathrm{~d} \mathrm{~N}$-free period was divided into two $6 \mathrm{~d}$ subperiods either with or without the abomasal infusion of clenbuterol (6$10 \mu \mathrm{g} / \mathrm{kg}$ per d). On the last day of each $6 \mathrm{~d}$ subperiod, protein turnover was estimated from the irreversible loss rate of $\mathrm{L}-\left[4,5-{ }^{3} \mathrm{H}\right]$ leucine given by jugular infusion. For three of the 
measurements, the animals were given clenbuterol in the first $6 \mathrm{~d}$ subperiod (measurements $A, B$ and $C$ ), and for the other four in the second (measurements $D_{1}, D_{2}, E$ and $F$ ).

\section{Animals}

Four female lambs of initially $32 \cdot 5-34.5 \mathrm{~kg}$ and approximately 4 months of age, and two ewes of initially 69 and $44 \mathrm{~kg}$ were used. The second ewe (animal D) was used twice. Each was fitted with a rumen cannula and abomasal catheter as described by Hovell et al. (1987).

\section{Housing and management}

The animals were housed in metabolism crates and entirely nourished by the intragastric infusion of all nutrients with the continuous infusion of VFA into the rumen, and protein (casein) into the abomasum as described by Hovell et al. (1987). The intragastric infusion was started after an overnight fast, at about $80 \mathrm{~kJ}$ VFA $/ \mathrm{kg}$ live weight $(\mathrm{W})^{0.75}$ per $\mathrm{d}$ and increased over about 1 week to supply approximately $450 \mathrm{~kJ}$ as VFA and $500 \mathrm{mg}$ casein$\mathrm{N} / \mathrm{kg} \mathrm{W}^{0.75}$ per d. Vitamins were mixed with the casein, or given with minerals and trace elements as a daily dose directly into the abomasum during casein-free periods.

Once established on infusion each animal was weighed and all calculations were based on these weights. Bilateral jugular catheters were used for blood sampling and the infusion of leucine. For blood sampling a silastic catheter $(0.8 \mathrm{~mm}$ i.d., $1.7 \mathrm{~mm}$ o.d.; Dow Corning, Reading, Berks.) was inserted about $200 \mathrm{~mm}$. For the intravenous infusion of labelled leucine, a polyvinyl chloride catheter $(1.0 \mathrm{~mm}$ i.d., $1.6 \mathrm{~mm}$ o.d.; Portex, Hythe, Kent) was inserted about $300 \mathrm{~mm}$ into the other jugular vein. The catheters were kept patent by twice daily flushing with sterile heparinized $(400 \mathrm{i} . \mathrm{u} . / \mathrm{ml})$ physiological saline $(9 \mathrm{~g}$ sodium chloride/1).

After catheterization each animal was started on the $12 \mathrm{~d}$ experimental period of $\mathrm{N}$-free infusion. The VFA infusion was maintained, and the casein abruptly withdrawn, with the same volume of water being infused into the abomasum. When given, the clenbuterol was dissolved in the water infused into the abomasum and infused over a period of about $23 \mathrm{~h}$. Initially the dose of clenbuterol used was about $6 \mu \mathrm{g} / \mathrm{kg}$ per d, similar to that we had used before (Hovell et al. 1989). However, we became concerned that we might be on the threshold of the response dose, since the effect on $\mathrm{UN}_{\mathrm{E}}$ appeared to be small and, therefore, the dose was increased (Table 1).

Urine and faeces were collected in trays acidified with sulphuric acid, and measured and sampled daily. After several days on infusion, faecal output was small and intermittent and, therefore, was ignored in the calculation of $\mathrm{N}$ balance. Faecal debris was removed with a nylon sieve before sampling. Storage of urine was at or below $\mathrm{pH} 4$. N balance was based on the $24 \mathrm{~h}$ urine collection. A $6 \mathrm{~h}$ collection was made during the period of leucine infusion to check the stability of the $\mathrm{N}$ excretion. Differences between the $24 \mathrm{~h}$ collections and the $6 \mathrm{~h}$ subsamples were small, with no obvious bias, and, therefore, all calculations were based on $24 \mathrm{~h}$ total collections.

\section{Chemical analysis}

Urine samples were analysed for $\mathrm{N}$ by the automated Kjeldahl method of Davidson et al. (1970), for ammonia by the automated technique of Fawcett \& Scott (1960), for creatinine by the automated technique of Technicon Instruments Corp. (1965) which utilizes the Jaffe reaction, and for urea by the automated method of Technicon Instruments Corp. (Marsh et al. 1965). Purine derivatives were determined as uric acid after treatment with xanthine oxidase (EC 1.1.3.22) and as allantoin by automated techniques based on the methods of Technicon Instruments Corp. (1979) and Pentz (1969) (X.B. Chen and J. Mathieson, personal communication). 
Blood samples were prepared for analysis by precipitation of the protein by the addition of sulphosalicylic acid to a final concentration of $70 \mathrm{~g} / 1$ and analysed for amino acids as described by Lobley et al. (1980).

\section{Leucine kinetics and protein turnover}

On the last day of each $6 \mathrm{~d}$ subperiod each animal was given $\mathrm{L}-\left[4,5-{ }^{3} \mathrm{H}\right]$ leucine $(1 \mathrm{Ci} / \mathrm{mmol}$; Amersham International plc, Amersham, Bucks.) by jugular infusion. The leucine was diluted with sterile physiological saline to a final activity of $2.5 \mu \mathrm{Ci} / \mathrm{g}$, and infused at a rate of $20 \mathrm{~g} / \mathrm{h}$ for up to $7.5 \mathrm{~h}$. Six blood samples $(10 \mathrm{ml})$ were taken from the other jugular catheter at $0.5 \mathrm{~h}$ intervals during the last $2.5 \mathrm{~h}$ of infusion, immediately transferred into chilled heparinized tubes containing $2 \cdot 0 \mu \mathrm{mol} \mathrm{L}$-norleucine, and stored for up to $1 \mathrm{~h}$ in a refrigerator before preparation for analysis.

The specific radioactivity (SRA) of each set of plasma samples was plotted $v$. time to check that a satisfactory plateau SRA had been attained. Total body protein synthesis was calculated from the apparent irreversible loss (flux; Q) of blood-free leucine with the assumption that this loss occurred only by incorporation into body protein and by catabolism. Recycling was assumed not to occur during the $7.5 \mathrm{~h}$ infusion.

$\mathrm{Q}$ was calculated as:

$$
\mathrm{Q}(\mathrm{mmol} / \mathrm{h})=\frac{\text { infusion rate }(\mu \mathrm{Ci} / \mathrm{h})}{\text { SRA blood free-leucine }(\mu \mathrm{Ci} / \mathrm{mmol})} .
$$

$\mathrm{Q}$ was converted to $\mathrm{g}$ protein-N/d by multiplying by the factor 7.92 (from $\left.(24 \times 131) /\left(0.635 \times 10^{3} \times 6 \cdot 25\right)\right)$ as discussed by Reeds et al. $(1980)$, but with the modification that the average leucine content $(\mathrm{g} / \mathrm{g}$ protein) in sheep body protein was taken as 0.0635 (D. S. Brown and E. Storm, unpublished results).

Protein synthesis (S) was calculated as:

$$
\mathrm{S}=\text { protein } \mathrm{N} \text { flux }(\mathrm{Q} \times 7.92) \text { - amino acid oxidation }(\mathrm{E}) .
$$

Amino acid oxidation (plus other $\mathrm{N}$ losses from the animal due to protein catabolism; $\mathrm{E}$ ), was taken to be $\mathrm{UN}_{\mathrm{E}}$ on the day of measurement, less the $\mathrm{N}$ of creatinine, purine derivatives and an allowance for pyrimidine catabolism. Purine- $\mathrm{N}$ was calculated from purine derivative- $\mathrm{N}$ (hypoxanthine, xanthine, uric acid and allantoin) by correction for the initial hydrolysis of the purine. Pyrimidine- $\mathrm{N}$ was assumed to be half purine- $\mathrm{N}$. The total purine- and pyrimidine- $\mathrm{N}$ was thus calculated by multiplying purine derivative- $\mathrm{N}$ excretion by the factor 1.88 .

\section{Statistical analysis}

Animals were treated as replicates for analysis of variance. The second and separate measurement made with one animal (sheep D) was also treated as an independent observation, giving a total of seven measurements for the control and clenbuterol treatments, and a within-animal comparison. Consecutive measurements made within an animal and within a treatment subperiod (e.g. daily $\mathbf{N}$ balance or six half-hourly plasma samples) were deemed not to be independent, and the analysis of variance was carried out on the averaged within-animal values. Where the analysis was for the effect of different days, then the observations on each animal within $1 \mathrm{~d}$ were deemed to be independent, and were analysed as such. The statistical package GENSTAT 5 (Lawes Agricultural Trust, Rothamsted Experimental Station) was used to process the values. Significance was tested by Student's two-tailed test. The variance (s.flux) of a single measurement of protein flux was calculated from the variance (s.SRA) of the plateau values for plasma leucine SRA (from equation 1 above when ' $I$ ' was the infusion rate) as:

$$
\text { s.flux }=\left(I^{2} \times \text { s.SRA }\right) / \text { SRA }^{4} \text { (Kendell \& Stuart, 1963). }
$$




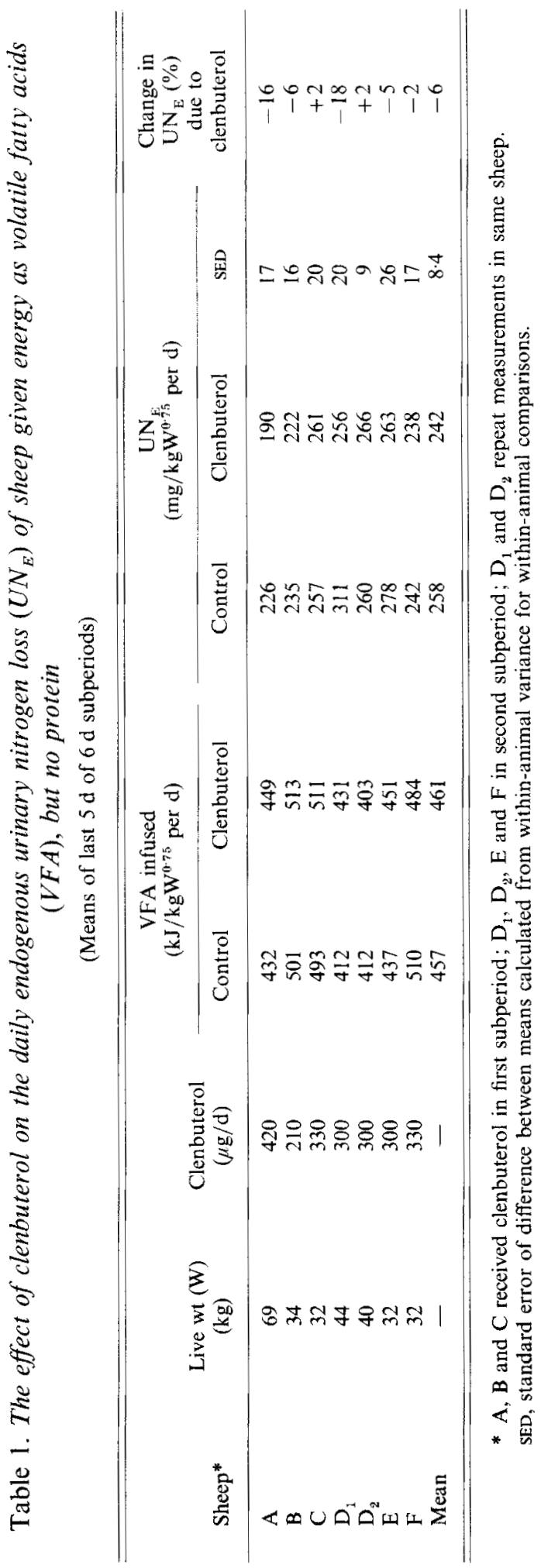


Table 2. The effect of clenbuterol on exogenous urinary nitrogen loss $\left(U N_{E}\right)$ and of urinary urea, ammonia, creatinine and purine derivatives of sheep

(Means of seven sheep)

\begin{tabular}{|c|c|c|c|c|c|c|c|}
\hline & \multirow{2}{*}{$\begin{array}{r}\mathrm{ME}^{*} \\
(\mathrm{KJ} / \mathrm{d})\end{array}$} & \multirow[b]{2}{*}{$\mathrm{UN}_{\mathbf{E}}^{\dagger}$} & \multicolumn{4}{|c|}{ Urine $\mathrm{N}\left(\mathrm{mg} / \mathrm{kgW}^{0 \cdot 75}\right.$ per $\left.\mathrm{d}\right)$} & \multirow[b]{2}{*}{ Accountable $N \$(\%)$} \\
\hline & & & Urea & $\mathrm{NH}_{3}$ & Creatinine & Purine & \\
\hline \multicolumn{8}{|c|}{ Subperiod ( $5 \mathrm{~d}$ means) } \\
\hline Control & 457 & 258 & $148 \cdot 1$ & $28 \cdot 2$ & $18 \cdot 7$ & $8 \cdot 8$ & $78 \cdot 1$ \\
\hline Clenbuterol & 461 & 242 & 144.9 & 21.4 & $19 \cdot 0$ & $8 \cdot 8$ & $80 \cdot 4$ \\
\hline SED & $6 \cdot 5$ & $8 \cdot 4$ & $7 \cdot 0$ & $4 \cdot 4$ & 0.45 & 0.43 & $3 \cdot 8$ \\
\hline \multicolumn{8}{|c|}{ Subperiod (daily means) } \\
\hline Day: 2 & 460 & 267 & $162 \cdot 4$ & $43 \cdot 6$ & $19 \cdot 3$ & $9 \cdot 1$ & $83 \cdot 7$ \\
\hline 3 & 460 & 265 & $158 \cdot 1$ & $24 \cdot 0$ & $19 \cdot 1$ & $9 \cdot 8$ & $76 \cdot 4$ \\
\hline 4 & 443 & 262 & $140-1$ & $35 \cdot 3$ & $18 \cdot 8$ & $9 \cdot 1$ & $76 \cdot 7$ \\
\hline 5 & 445 & 245 & 1467 & $20 \cdot 9$ & $18 \cdot 2$ & 8.1 & 78.4 \\
\hline 6 & 472 & 240 & $138 \cdot 5$ & $17 \cdot 6$ & $18 \cdot 2$ & $8 \cdot 2$ & $75 \cdot 4$ \\
\hline \multicolumn{8}{|l|}{ Clenbuterol } \\
\hline Day: 2 & 453 & 200 & $113 \cdot 2$ & $19 \cdot 6$ & $19 \cdot 5$ & $9 \cdot 6$ & $82 \cdot 3$ \\
\hline 3 & 455 & 250 & $158 \cdot 6$ & $25 \cdot 0$ & $18 \cdot 7$ & 8.9 & $84 \cdot 5$ \\
\hline 4 & 462 & 261 & $163 \cdot 3$ & $20 \cdot 1$ & $19 \cdot 1$ & $7 \cdot 8$ & $80 \cdot 0$ \\
\hline 5 & 465 & 257 & 169.6 & $25 \cdot 7$ & $19 \cdot 0$ & 8.7 & 78.0 \\
\hline 6 & 472 & 244 & 144.9 & $17 \cdot 4$ & 18.7 & $9 \cdot 1$ & $77 \cdot 2$ \\
\hline SED & $14 \cdot 1$ & $14 \cdot 3$ & 15.9 & 9.6 & 0.53 & 0.72 & 4.4 \\
\hline
\end{tabular}

* Energy infused as volatile fatty acids into the rumen.

$\dagger$ Kjeldahl N.

+ Purine derivatives (xanthine, hypoxanthine, uric acid and allantoin).

$\S$ Sum of urea-, ammonia-, creatinine- and purine derivative- $N$.

SED, standard error of difference between means; W, live weight; $M E$, metabolizable energy.

\section{RESULTS}

\section{Animal health and management of infusion}

No major health problems occurred. When the drug was introduced, a slight muscle tremor was observed initially, but not the tachycardia we have observed with higher doses (Herbert et al. 1985). Animal D had mild haematuria when clenbuterol was given. Since we have observed mild haematuria on other occasions with the infused animals, we do not believe it to have been associated with clenbuterol treatment. She was repleted with a casein infusion for 3 weeks, and then measurements were repeated. On both occasions animal D exhibited a large live-weight loss which could only be explained as water, and presumably as a fluctuation in the gastrointestinal tract pool size (the $\mathrm{N}$ loss was not abnormal). With the exception of animal D, weight losses over the $12 \mathrm{~d}$ of the experiment were $0.5 \mathrm{~kg}$ or less. The $\mathrm{UN}_{\mathrm{E}}$ of sheep $\mathrm{D}$ was very similar for the two measurements with clenbuterol. The two turnover measurements with animal $D$ were rather different, but not abnormal in the context of the values obtained with the other animals. Therefore, the values from both measurements of turnover and $\mathrm{N}$ excretion made with this animal have been included in the results presented.

\section{$N$ excretion}

$\mathrm{UN}_{\mathrm{E}}$ values are given in Table 1. Excretion during the control periods ranged from 220 to $311 \mathrm{mg} / \mathrm{kg} \mathrm{W}^{0.75}$ per $\mathrm{d}$, and from 190 to $266 \mathrm{mg} / \mathrm{kg} \mathrm{W}^{0.75}$ per $\mathrm{d}$ when clenbuterol was given. 
Table 3. The relative contributions of creatinine, purine derivatives and urea plus ammonia to the endogenous urinary excretion of total (Kjeldahl) nitrogen $\left(U N_{E}\right)$ by sheep during the $12 d$ period of $N$-free nutrition

(Means of seven sheep)

\begin{tabular}{|c|c|c|c|c|c|}
\hline \multirow[b]{2}{*}{ Day } & \multirow{2}{*}{$\begin{array}{c}\mathrm{UN}_{\mathrm{E}^{\mathrm{V}}} \\
\left(\mathrm{mg} / \mathrm{kg} \mathrm{W}^{0.75} \text { per d) }\right. \\
(\text { Kjeldahl } \mathrm{N})\end{array}$} & \multicolumn{3}{|c|}{ Contribution $(\%)$ to $\mathrm{N}$ of $\mathrm{UN}_{\mathbf{E}}$} & \multirow{2}{*}{$\begin{array}{c}\text { Total accountable } \\
\mathrm{N} \dagger(\%)\end{array}$} \\
\hline & & Creatinine & Purine* & $\mathrm{Urea}+\mathrm{NH}_{3}$ & \\
\hline 1 & 310 & 6.8 & $4 \cdot 5$ & 75.7 & 87.7 \\
\hline 2 & 251 & $8 \cdot 8$ & $4 \cdot 6$ & 72.6 & 86.8 \\
\hline 3 & 256 & $7 \cdot 8$ & $4 \cdot 1$ & 73.8 & $84 \cdot 2$ \\
\hline 4 & 262 & 7.6 & $3 \cdot 6$ & 69.6 & 80.6 \\
\hline 5 & 251 & $7 \cdot 8$ & $3 \cdot 3$ & $69 \cdot 8$ & $80 \cdot 3$ \\
\hline 6 & 240 & $8 \cdot 1$ & 3.7 & 67.0 & $78 \cdot 5$ \\
\hline 7 & 236 & $9 \cdot 0$ & $4 \cdot 7$ & 62.5 & $76 \cdot 3$ \\
\hline 8 & 227 & $8 \cdot 5$ & 3.9 & $66 \cdot 2$ & $79 \cdot 2$ \\
\hline 9 & 259 & $7 \cdot 4$ & $3 \cdot 4$ & $67 \cdot 4$ & 76.7 \\
\hline 10 & 261 & $7 \cdot 2$ & $3 \cdot 1$ & $67 \cdot 0$ & $76 \cdot 1$ \\
\hline 11 & 252 & $7 \cdot 3$ & $3 \cdot 5$ & 66.4 & $76 \cdot 1$ \\
\hline 12 & 244 & $7 \cdot 4$ & 3.5 & $64 \cdot 4$ & $74 \cdot 2$ \\
\hline SED & 17 & 0.66 & $0 \cdot 44$ & 3.6 & 3.6 \\
\hline
\end{tabular}

* Xanthine, hypoxanthine, uric acid and allantoin.

$\dagger$ Sum of contributions of creatinine, purine and urea $+\mathrm{NH}_{3}$. Calculated on individual samples and, therefore, not identical with summed means.

SED, standard error of difference between means; $W$, live weight.

Table 4. Plasma amino acid concentrations (nmol/g) of sheep maintained on nitrogen-free nutrition measured during the last day of $6 d$ subperiods with or without clenbuterol infusion, or shown as day 6 or day 12 of the $12 \mathrm{~d}$ period

(Means of seven sheep. The seven values whose means are presented were each the average of the six plasma samples analysed for each measurement of leucine flux)

\begin{tabular}{|c|c|c|c|c|c|}
\hline & \multicolumn{2}{|c|}{ Treatment } & \multicolumn{2}{|c|}{ Subperiod (time effect) } & \multirow[b]{2}{*}{ SED } \\
\hline & Control & Clenbuterol & Day 6 & Day 12 & \\
\hline Aspartic acid & $37 \cdot 4$ & $32 \cdot 8$ & $40 \cdot 9$ & $29 \cdot 3$ & 6.7 \\
\hline Glutamic acid & $212 \cdot 0$ & $261 \cdot 0$ & $275 \cdot 0$ & $198 \cdot 0$ & $38 \cdot 3$ \\
\hline Glutamine & 119.6 & $125 \cdot 7$ & $127 \cdot 2$ & $118 \cdot 1$ & $7 \cdot 0$ \\
\hline Glycine & $647 \cdot 0$ & $629 \cdot 0$ & $595 \cdot 0$ & $681 \cdot 0$ & $85 \cdot 8$ \\
\hline Alanine & $179 \cdot 0$ & $200 \cdot 0$ & $189 \cdot 0$ & $189 \cdot 0$ & $23 \cdot 6$ \\
\hline Valine & $60 \cdot 6$ & 63.8 & 63.7 & $60 \cdot 8$ & $3 \cdot 2$ \\
\hline Cysteine & 6.4 & $7 \cdot 2$ & 6.8 & $6 \cdot 8$ & $1 \cdot 2$ \\
\hline Methionine & $13 \cdot 3$ & $13 . \overline{6}$ & $14 \cdot 2$ & $12 \cdot 7$ & $2 \cdot 2$ \\
\hline Isoleucine & $10 \cdot 5$ & $10 \cdot 4$ & 11.6 & 9.2 & 14 \\
\hline Leucine & $54 \cdot 2$ & $53 \cdot 9$ & $53 \cdot 4$ & $54 \cdot 7$ & $5 \cdot 1$ \\
\hline Tyrosine & $18 \cdot 8$ & $19 \cdot 0$ & $20 \cdot 7$ & $17 \cdot 2$ & $2 \cdot 1$ \\
\hline Phenylalanine & $21 \cdot 3$ & $22 \cdot 8$ & $24 \cdot 2$ & $19 \cdot 9$ & $2 \cdot 8$ \\
\hline Histidine & $79 \cdot 3$ & $78 \cdot 5$ & $73 \cdot 8$ & $84 \cdot 0$ & $4 \cdot 8$ \\
\hline Lysine & 89.6 & $74 \cdot 3$ & $88 \cdot 2$ & $75 \cdot 7$ & $8 \cdot 6$ \\
\hline Arginine & $46 \cdot 0$ & $42 \cdot 5$ & $46 \cdot 5$ & $41 \cdot 9$ & $4 \cdot 1$ \\
\hline Proline & $61 \cdot 2$ & $68 \cdot 0$ & $64 \cdot 5$ & $64 \cdot 7$ & $4 \cdot 9$ \\
\hline
\end{tabular}




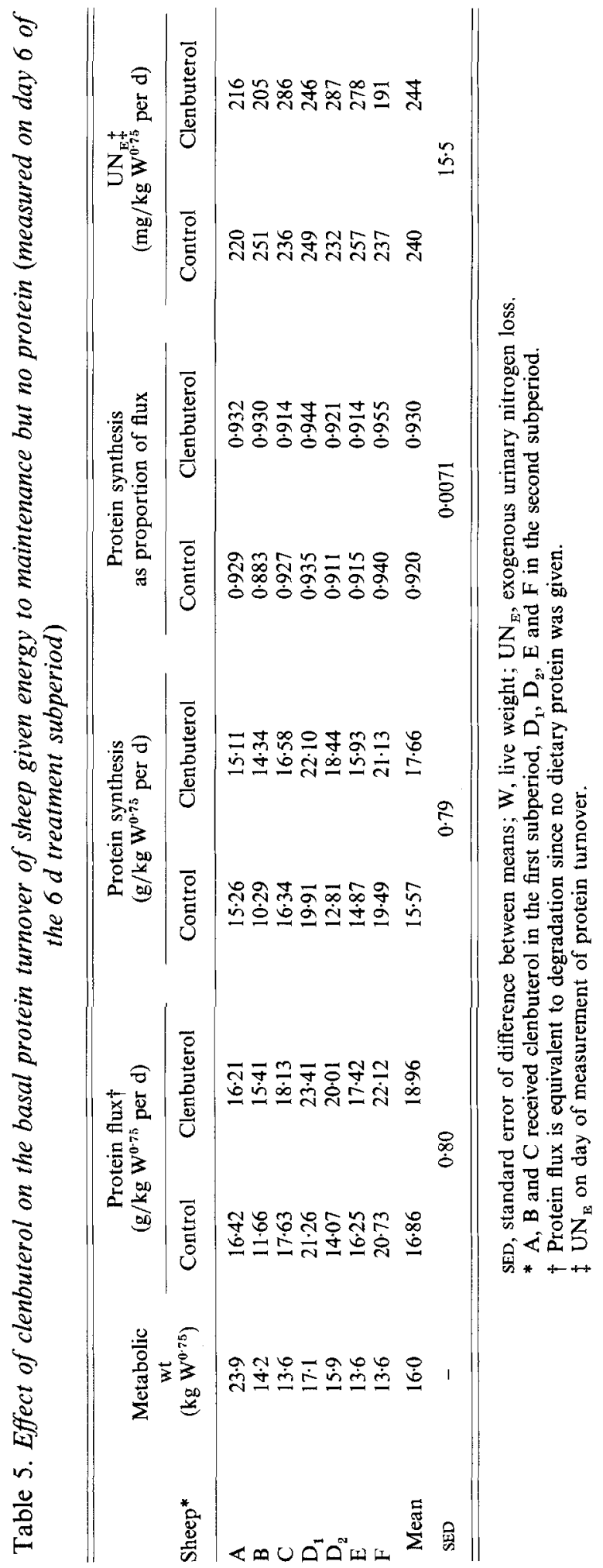


Clenbuterol again tended to reduce $\mathrm{UN}_{\mathrm{E}}$, but only by an average of $6 \%(P<0 \cdot 10)$. However, clenbuterol did produce a significant $(P<0.01)$ reduction in $\mathrm{UN}_{\mathrm{E}}$ on day 2 , which when compared with the mean control was an average reduction of $\mathrm{UN}_{\mathrm{E}}$ of $22 \%$. However, the effect was not maintained (Table 2). About 0.7 of the reduction in $\mathrm{UN}_{\mathrm{E}}$ was in the urea and ammonia fractions, and 0.3 in an unidentified fraction. There was no effect on creatinine or purine excretion, both of which remained relatively constant throughout the experimental periods (Table 2).

\section{Unidentified urinary $N$}

When the contributions of urea, ammonia, creatinine and purine derivatives to $\mathrm{N}$ excretion were summed and expressed as a proportion of the total urinary $\mathrm{N}$ measured by Kjeldahl digestion, about $20 \%$ of Kjeldahl $\mathrm{N}$ was unaccounted for. There was the suggestion that recovery was higher early in the period, and the values were examined in more detail. This showed a progressive decline in the $\mathrm{N}$ which could be accounted for as the $\mathrm{N}$-free period progressed (Table 3) which was independent of treatment. The relationship between the time and total $\mathrm{N}$ recovered was highly significant $(P<0.001)$. The proportion of $\mathrm{N}$ accounted for $(Y)$ declined by about one percentage unit daily $(Y=87 \cdot 6-1 \cdot 16 \times$ day number, $\left.\mathrm{SE}_{\mathrm{b}} 0 \cdot 15\right)$.

\section{Plasma amino acids}

The mean plasma amino acid concentrations are given in Table 4 . There was no evidence of any effect of clenbuterol. There was the suggestion (not significant statistically), that concentrations tended to be lower in the second subperiod (ten from sixteen amino acids).

\section{Protein turnover}

The plateau specific activities were reasonably stable (SE on average was $2.9 \%$ of the mean). Clenbuterol increased both protein flux and protein synthesis $(P<0.05)$, with an average increase in protein flux of about $12 \%$. There was no relationship between protein flux and $\mathrm{UN}_{\mathrm{E}}$, which was unchanged by treatment on the day of measurement (Table 5). The response of protein flux to clenbuterol infusion was variable, and the between-animal variance was significant $(P<0.05$, coefficient of variation $17 \%)$. Animal A showed no response to clenbuterol, and flux was unchanged. However animal $A$ had shown a reduction in $\mathrm{UN}_{\mathrm{E}}$ on day 2 with clenbuterol ( $U \mathrm{~N}_{\mathrm{E}}$ on day 2 was $146 \mathrm{mg} \mathrm{N} / \mathrm{kg} \mathrm{W}^{0.75}$ per d).

The difference between treatments when synthesis was expressed as a proportion of flux was not significant statistically (Table 5) but had to be real, since $\mathrm{UN}_{\mathrm{E}}$ and the constituents of $\mathrm{UN}_{\mathrm{E}}$ were unchanged (Tables 2 and 5). (The reduction of oxidation from 0.08 of flux to 0.07 of flux represents a reduction of $12 \%$.)

\section{DISCUSSION \\ $N$ excretion}

The $6 \%$ reduction of $\mathrm{UN}_{\mathrm{E}}$ with clenbuterol was less then the $14 \%$ reduction $(P<0.05)$ we reported previously (Hovell et al. 1989). As in our earlier report, the effect was very variable between animals, the change in $\mathrm{UN}_{\mathrm{E}}$ ranged from a reduction of $18 \%$ to an increase of $2 \%$. We had also reported previously (Hovell et al. 1989) a relationship between $\Delta \mathrm{UN}_{\mathrm{E}}(Y)$ and $\mathrm{UN}_{\mathrm{E}}(X)$. No such relationship was apparent here $\left(Y=83-0 \cdot 32 X, \mathrm{SE}_{\mathrm{b}} 0 \cdot 69, r 0 \cdot 42\right)$. The greater initial effect on the reduction of $\mathrm{UN}_{\mathrm{E}}$ is in agreement with our earlier finding (Hovell et al. 1989). The mean creatinine excretion of 51.6 (sD $5 \cdot 2$ ) $\mathrm{mg} / \mathrm{kg} \mathrm{W}^{0.75}$ per d compares well with those of 49.3 (SD 2.9$) \mathrm{mg} / \mathrm{kg} \mathrm{W}^{0.75}$ per d and 53.4 (SD 4.8 ) $\mathrm{mg} / \mathrm{kg} \mathrm{W}^{0.75}$ per $\mathrm{d}$ obtained by Hovell et al. $(1987,1989)$ from $\mathrm{N}$-free infused wethers and ewes. The mean 
endogenous excretion of purine derivatives (allantoin equivalent) of 27.5 (SD 3.4 ) $\mathrm{mg} / \mathrm{kg}$ $\mathrm{W}^{0 \cdot 75}$ per $\mathrm{d}$ compared well with the 23 (SD 7.7) $\mathrm{mg} / \mathrm{kg} \mathrm{W}^{0.75}$ per $\mathrm{d}$ reported by Fujihara et al. (1988) with slightly younger lambs.

\section{Unidentified urinary $N$}

The use of urea plus ammonia excretion as an estimator of amino acid oxidation was shown by Reeds et al. (1980) to correlate well $(r 0.98$, slope 1.01) with oxidation determined from ${ }^{14} \mathrm{CO}_{2}$. However, in the experiment reported here we were unable to account for all the urinary (Kjeldahl) $\mathbf{N}$.

We have been unable to account for all the Kjeldahl $\mathrm{N}$ in the urine of animals on some other infusion experiments, particularly when fasted, or on $\mathrm{N}$-free nutrition (unpublished observations). Repeated checks have been unable to identify any analytical error, and work is currently in progress to identify the missing component(s). About $0 \cdot 3$ of the reduction of $\mathrm{UN}_{\mathrm{E}}$ was in this unidentified component and it is probable that most of the unidentified $\mathrm{N}$ arose from protein catabolism, and that urea plus ammonia would thus underestimate the true loss to the animal of $\mathrm{N}$ arising from protein flux. Further analysis of urine samples from other experiments has suggested that certainly half the unaccountable $\mathrm{N}$ is amino- $\mathrm{N}$ (unpublished observations). Therefore, the loss of protein- $\mathrm{N}$ to the animal was taken as $\mathrm{UN}_{\mathrm{E}}$, less the loss of $\mathrm{N}$ as creatinine and that due to purine and pyrimidine catabolism.

\section{Basal protein turnover}

The mean protein flux of $16.86(\mathrm{SE} 0.56) \mathrm{g} / \mathrm{kg} \mathrm{W}^{0.75}$ per $\mathrm{d}$, measured during the control subperiod (Table 5) is of the same order as the mean values reported and cited by Krishnamurti \& Janssens (1988) of from 8.0 to $20.4 \mathrm{~g} / \mathrm{kg} \mathrm{W} \mathrm{W}^{0.75}$ per d for wethers and dry ewes of between 42 and $67 \mathrm{~kg}$ live weight. All the values referred to previously were also determined by plasma amino acid flux (tyrosine or leucine) and, therefore, have that base in common. However, whereas the published values all relate to fed animals given protein and which were at or above protein equilibrium, our measurements were made when the animals were receiving energy but not protein, and should be representative of the basal state.

An advantage of the infused animals is that all $\mathrm{N}$ is excreted in the urine, since there is no rumen or hind-gut fermentation. Therefore, losses of amino- $\mathrm{N}$ to oxidation can be estimated from urine- $\mathrm{N}$, which when corrected for creatinine and $\mathrm{N}$ estimated to come from purines and pyrimidines was 0.075 of flux (average of all values, Table 4). When estimated from urea plus ammonia alone, oxidation was estimated as 0.057 (overall mean) of flux. Thus, synthesis was, on average, between 0.943 and 0.925 of flux, but the general findings of the study reported here were unchanged since clenbuterol had no effect on the relative proportions of urine constituents.

Our values for the control treatment of $16.86 \mathrm{~g} / \mathrm{kg} \mathrm{W}^{0.75}$ per $\mathrm{d}$ for basal protein flux (equal to degradation for animals receiving no exogenous amino- $\mathrm{N}$ ), and $15.57 \mathrm{~g} / \mathrm{kg} \mathrm{W}^{0.75}$ per d for protein synthesis with a $\mathrm{UN}_{\mathrm{E}}$ of $258 \mathrm{mg} \mathrm{N} / \mathrm{kg} \mathrm{W}^{0.75}$ per d and losses to oxidation of 0.080 of flux, compare with those reported by Lobley et al. (1987) for fasting steers (mean weight $437 \mathrm{~kg}$ ) which had a protein flux and synthesis respectively of 21.27 and $18.26 \mathrm{~g} / \mathrm{kg}$ $\mathrm{W}^{0.75}$ per $\mathrm{d}$, and a urinary $\mathrm{N}$ loss of $513 \mathrm{mg} / \mathrm{kg} \mathrm{W}^{0.75}$ per $\mathrm{d}$, with losses to oxidation of 0.122 of flux.

In the experiment reported here the infusion of VFA was very steady, and the animals should have been stable. Even so there was a considerable between-animal variation, and the two measurements with sheep D gave total fluxes during the control subperiods of 364 and $224 \mathrm{~g}$ protein/d (SE of difference (SED) $9 \mathrm{~g} / \mathrm{d}$ ). (The SED of these two values which was based on SE of plateau SRA as described previously should include all sampling and 
analytical errors.) Although clenbuterol increased flux on both occasions, these two different values are presumably indicative of within-animal or methodological variation.

\section{Effect of clenbuterol}

All the reports in the literature of the effect of $\beta_{2}$-agonists on protein turnover in a range of species relate to animals which were already in a state of positive $\mathrm{N}$ accretion before the drug was given, and most relate to skeletal muscle. In their review, Buttery \& Dawson (1987) concluded that the improved $\mathrm{N}$ accretion resulting from treatment with $\beta$-agonists was due to reduced muscle degradation. This is supported by the observation of Wang \& Beerman (1988) that cimaterol-treated lambs had a reduced level of muscular calciumdependent protease. However, there are also reports of an increased muscle protein synthesis in rats (Emergy et al. 1984) and mice (Pell et al. 1987). In experiments in which measurements of whole-body protein metabolism have been made with fed sheep given clenbuterol, Bohorov et al. (1987) found no increase in tyrosine flux, while MacRae et al. (1988) who measured leucine flux at 4,11 and $18 \mathrm{~d}$ after initiating treatment, found no increase in oxidation corrected leucine flux (i.e. synthesis) at 4 and $18 \mathrm{~d}$, but did find an increase at $11 \mathrm{~d}$. Both authors concluded that degradation was reduced in all periods and was the cause of the increased $\mathrm{N}$ retention. In the experiment reported here, in which energy but no protein was supplied, both synthesis and degradation were increased, whereas overall $\mathrm{N}$ status relative to the control was unchanged.

Our measurement of protein turnover was made on the sixth day of treatment with the drug, a factor which may have been important, for as the work reported here and previously (Hovell et al. 1989) demonstrated, the initial reduction in $\mathrm{N}$ loss when clenbuterol and cimaterol were given was not maintained. Thus, the effect on turnover may have been different on day 2. There are other examples of time after treatment affecting the effect of $\beta$-agonists. We have shown in this Institute (Herbert et al. 1985; Brockway et al. 1987) that clenbuterol caused a considerable tachycardia and slight increase in rectal temperature in sheep when given at $1.5 \mathrm{mg} / \mathrm{d}$, but that these effects only lasted for about $30 \mathrm{~h}$, whereas the effect on $\mathrm{N}$ accretion persisted. MacRae et al. (1988) found with normally fed sheep a rapid (and variable) increase in energy expenditure which declined over $20 \mathrm{~d}$, whereas the effect on $\mathrm{N}$ accretion was maintained and Maltin et al. (1987) found a timerelated effect in the way in which enhanced accretion in denervated muscle was mediated.

The response within a tissue can also differ between different muscles and muscle fibre types (Maltin et al. 1986, 1987; Beerman et al. 1987; Kim et al. 1987). One of the interesting features of these drugs is their effect on increasing $\mathrm{N}$ accretion through reduced protein degradation while also increasing general energy expenditure (see Buttery \& Dawson 1987; Williams, 1987) presumably due to an increased flux of other metabolic cycles. In this context the increased protein flux observed in the experiment reported here is consistent with a generally enhanced rate of metabolic activity and substrate cycling.

It is not certain that the effect on muscle protein accretion is due to a specific $\beta$-agonist effect, for Reeds et al. (1988) have shown in rats that the $\beta$-antagonists propranolol and atenolol blocked the effect of clenbuterol on energy expenditure (thought to be $\beta$ mediated), but not the effect on increasing $\mathrm{N}$ accretion. However mediated, the effects of $\beta$-agonists on enhancing $\mathrm{N}$ accretion appear to be specific to muscle (Reeds et al. 1986). Therefore, it could be that the effect reported here on increasing protein flux during $\mathrm{N}$-free nutrition demonstrated a different response to clenbuterol within specific tissues (e.g. muscle) from that of animals receiving exogenous protein. Alternatively it could have reflected the activities of, and effect on, other protein pools whose response to clenbuterol is different from that of muscle. Examples are the gastrointestinal tract, and the liver, whose greater metabolic activity make a greater contribution to whole-body protein flux than 
muscle. Thus, the sum of synthesis due to the liver, gastrointestinal tract and skin of cattle and sheep was reported to be 0.4 to 0.6 of whole-body synthesis, whereas that of skeletal muscle was $0 \cdot 2$ to 0.3 of whole-body synthesis (Lobley et al. 1980; Davis et al. 1981; Attaix et al. 1988). In the $\mathrm{N}$-free state, the relative contribution of the skin and body organs is greater, for McNurlan et al. (1982) showed the fractional synthesis rate of protein in the liver and jejunal mucosa of rats after $9 \mathrm{~d} \mathrm{~N}$-free nutrition to be reduced to about 0.8 of that of the fed controls, while that of gastrocnemius muscle was reduced to about 0.2 of that of the controls.

A possible interpretation of the effect of clenbuterol increasing whole-body protein flux in the experiment reported here could be a $\beta$-agonist stimulation acting mainly on protein pools other than muscle, in a way comparable with the $\beta$-agonist effect on general metabolism (i.e. increasing flux), whereas with animals receiving exogenous protein this is masked by the anabolic effect on skeletal muscle. In this context, the 'repartitioning' effect of clenbuterol and cimaterol on increasing the deposition of carcass protein (skeletal muscle), and not changing or even decreasing deposition in the non-carcass proteins of the organs and skin of protein-fed rats (Reeds et al. 1988; Sainz \& Wolff, 1988) and calves (Williams, 1987), may be of relevance.

\section{Conclusion}

The effects of clenbuterol are multifaceted and, therefore, appear complex. In the work reported here with sheep given energy but not protein, clenbuterol caused an initial fall in $\mathrm{N}$ loss $\left(\mathrm{UN}_{\mathrm{E}}\right)$. However, this change was not persistent, for $\mathrm{UN}_{\mathrm{E}}$ returned to normal within a few days. The apparent return to normality masked an increase in protein flux (synthesis and degradation) with no increase in oxidation. The magnitude of these effects was variable between animals, and there was no confirmation of an earlier observation that the change in $\mathrm{UN}_{\mathrm{E}}$ caused by the drug was related to $\mathrm{UN}_{\mathrm{E}}$ when no drug was given.

The work was financed in part by Merck and Co. Inc. to whom the authors are also grateful for the gift of the clenbuterol. The help of V. Buchan, S. Gauld, M. Annand, M. Waldron and N. Mossom for the analysis of plasma and urine samples, of X. B. Chen for the purine derivative analysis and of $\mathrm{Mrs} \mathrm{H}$. Vint for statistical advice is also gratefully acknowledged.

\section{REFERENCES}

Attaix, D., Aurousseau, E., Manghebati, A. \& Arnal, M. (1988). Contribution of liver, skin and skeletal muscle to whole-body protein synthesis in the young lamb. British Journal of Nutrition 60, 77-88.

Beerman, D. H., Boyd, R. D., Fishell, V. K. \& Ross, D. A. (1987). A comparison of the repartitioning effects of cimaterol and somatotrophin on skeletal muscle. Federation Proceedings 29, 1375-1378.

Bohorov, O., Buttery, P. J., Correia, J. H. R. D. \& Soar, J. B. (1987). The effect of the $\beta$-2-adrenergic agonist clenbuterol or implantation with oestradiol plus trenbolone acetate on protein metabolism in wether lambs British Journal of Nutrition 57, 99-107.

Brockway, J. M., MacRae, J. C. \& Williams, P. E. V. (1987). Side effects of clenbuterol as a repartitioning agent. Veterinary Record 120, 381-383.

Buttery, P. J. \& Dawson, J. M. (1987). The mode of action of beta-agonists as manipulators of carcass composition. In Beta-agonists and Their Effects on Animal Growth and Carcass Quality, pp. 29-43 [J. P. Hanrahan, editor]. London: Elsevier Applied Science.

Davidson, J., Mathieson, J. \& Boyne, A. W. (1970). The use of automation in determining nitrogen by the Kjeldahl method, with final calculation by computer. Analyst, London 95, 181-193.

Davis, S. R., Barry, T. N. \& Hughson, G. A. (1981). Protein synthesis of growing lambs. British Journal of Nutrition 46, 409-419.

Emery, P. W., Rothwell, N. J., Stock, M. J. \& Winter, P. D. (1984). Chronic effects of $\beta_{2}$-adrenergic agonists on body composition and protein synthesis in the rat. Bioscience Reports 4, 83-91.

Fawcett, J. K. \& Scott, J. E. (1960). The determination of urea and ammonia in biological fluids. Journal of Clinical Pathology 13, 156-159. 
Fujihara, T., Chen, X. B., Ørskov, E. R. \& Hovell, F. D. DeB. (1988). The possible use of purine derivatives in the urine to estimate rumen microbial protein production. Proceedings of the 5th International Symposium on Protein Metabolism and Nutrition. European Association for Animal Production Publication no. 35, pp. 2-S, $17-18$.

Herbert, F., Hovell, F. D. DeB. \& Reeds, P. J. (1985). Some preliminary observations on the immediate effects of clenbuterol on heart rate, body temperature and nitrogen retention in lambs wholly nourished by intragastric infusion. Proceedings of the Nutrition Society 44, 150A.

Hovell, F. D. DeB., Kyle, D. J., Reeds, P. J. \& Beerman, D. H. (1989). The effect of clenbuterol and cimaterol on the basal nitrogen excretion of sheep. Nutrition Reports International 39, 1177-1182.

Hovell, F. D. DeB., Ørskov, E. R., Kyle, D. J. \& MacLeod, N. A. (1987). Undernutrition in sheep. Nitrogen repletion by $\mathrm{N}$-depleted sheep. British Journal of Nutrition $\mathbf{5 7}, 77-88$.

Kendell, M. G. \& Stuart, A. (1963). The Advanced Theory of Statistics, vol. 1. pp. 232-233. London: Charles Griffen.

Kim, Y. S., Lee, Y. B. \& Dalrymple, R. H. (1987). Effect of the repartitioning agent cimaterol on growth, carcass and skeletal muscle characteristics in lambs. Journal of Animal Science 65, 1392-1399.

Krishnamurti, C. R. \& Janssens, S. M. (1988). Determination of leucine metabolism and protein turnover in sheep using gas chromatography-mass spectrometry. British Journal of Nutrition 59, 155-164.

Lobley, G. E., Connel, A. \& Buchan, V. (1987). Effect of food intake on protein and energy metabolism in finishing beef steers. British Journal of Nutrition 57, 457-465.

Lobley, G. E., Milne, V., Lovie, J. M., Reeds, P. J. \& Pennie, K. (1980). Whole body and tissue protein synthesis in cattle. British Journal of Nutrition 43, 491-502.

McNurlan, M. A., Fern, E. B. \& Garlick, P. J. (1982). Failure of leucine to stimulate protein synthesis in vivo. Biochemical Journal 204, 831-838.

MacRae, J. C., Skene, P. A., Connell, A., Buchan, V. \& Lobley, G. E. (1988). The action of the $\beta$-agonist clenbuterol on protein and energy metabolism in fattening wether lambs. British Journal of Nutrition $\mathbf{5 9}$, 457-465.

Maltin, C. A., Hay, S. M., Delday, M. J., Smith, F. G., Lobley, G. E. \& Reeds, P. J. (1987). Clenbuterol, a beta agonist, induces growth in innervated and denervated muscle via apparently different mechanisms. Bioscience Reports 7, 525-532.

Maltin, C. A., Reeds, P. J., Delday, M. J., Hay, S. M., Smith, F. G. \& Lobley, G. E. (1986). Inhibition and reversal of denervation induced atrophy by the $\beta$-agonist growth promoter, clenbuterol. Bioscience Reports 6 , 811-817.

Marsh, W. H., Fingerhut, B. \& Miller, H. (1965). Automated and manual methods for determination of blood urea. Clinical Chemistry 11, 624-627.

Pell, J. M., Bates, P. C., Elcock, C., Lane, S. E. \& Simmonds, A. D. (1987). Growth hormone and clenbuterol: action and interaction on muscle growth, protein turnover and serum IGF-l concentrations in dwarf mice. Journal of Endocrinology 115, Suppl. 68 Abstr.

Pentz, E. I. (1969). Adaptation of the Rimini-Schryver reaction for the measurement of allantoin in urine to the autoanalyser. Analytical Biochemistry 27, 333-342.

Reeds, P. J., Cadenhead, A., Fuller, M. F., Lobley, G. E. \& McDonald, J. D. (1980). Protein turnover in growing pigs. Effects of age and food intake. British Journal of Nutrition 43, 445-455.

Reeds, P. J., Hay, S. M., Dorwood, P. M. \& Palmer, R. M. (1986). Stimulation of muscle growth by clenbuterol: lack of effect on muscle protein biosynthesis. British Journal of Nutrition 56, 249-258.

Reeds, P. J., Hay, S. M., Dorwood, P. M. \& Palmer, R. M. (1988). The effect of $\beta$-agonists and antagonists on muscle growth and body composition of young rats (Rattus sp.). Comparative Biochemistry and Physiology $89 \mathrm{C}$, $337-341$.

Sainz, R. D. \& Wolff, J. E. (1988). Effects of the $\beta$-agonist, cimaterol, on growth, body composition and energy expenditure in rats. British Journal of Nutrition 60, 84-90.

Technicon Instruments Corp. (1965). Creatinine. Method no. N11-A. Tarrytown, NY: Technicon Instruments Corp.

Technicon Instruments Corp. (1979). Uric acid. Method no. SD4 0013FM9. Tarrytown, NY: Technicon Instruments Corp.

Wang, S. Y. \& Beerman, D. H. (1988). Reduced calcium dependent proteinase activity in cimaterol-induced muscle hypertrophy in lambs. Journal of Animal Science 66, 2545-2550.

Williams, P. E. V. (1987). The use of $\beta$-agonists as a means of altering body composition in livestock species. Nutrition Abstracts and Reviews 57, 453-464. 